PRACE NAUKOWE UNIWERSYTETU EKONOMICZNEGO WE WROCLAWIU

\title{
Bogdan Gregor
}

Uniwersytet Łódzki

e-mail: prorekonom@uni.lodz.pl

\section{Lukasz Wdowiak}

Stratega Market Research

\section{ISTOTA ORAZ METODY \\ BADAŃ NEUROMARKETINGOWYCH}

\section{ESSENCE AND METHODS \\ OF NEUROMARKETING RESEARCH}

DOI: $10.15611 /$ pn.2016.459.05

JEL Classification: M31, M37

Streszczenie: Neuromarketing i badania neuromarketingowe to nowy obszar nauki odgrywający coraz większą rolę w marketingu i przedmiot ożywionej dyskusji metodologicznej w ramach badań marketingowych. Badania neuromarketingowe są skierowane na określenie reakcji mózgu na bodźce marketingowe. W artykule podjęto próbę przybliżenia istoty badań neuromarketingowych oraz stosowanych metod badawczych. Wykorzystywane są przede wszystkim metody zaczerpnięte z neurologii. Najwięcej miejsca poświęcono metodzie wykorzystującej elektroencefalografię (EEG). Dokonano oceny możliwości użycia tej metody w testowaniu przekazów reklamowych. W tym celu przeprowadzono eksperyment laboratoryjny z udziałem 20 osób w wieku 20-25 lat, który potwierdził użyteczność tej metody w projektowaniu skutecznych kampanii reklamowych. Wskazano na ograniczenia w wykorzystaniu technologii umożliwiającej monitorowanie pracy mózgu w badaniach neuromarketingowych. Zwrócono także uwagę na kwestie etyczne związane $\mathrm{z}$ neuromarketingiem.

Słowa kluczowe: neuromarketing, badania neuromarketingowe, elektroencefalografia (EEG), reklama.

Summary: Neuromarketing and neuromarketing research are a new area of science beginning to play a significant role in marketing. It also provokes a vivid marketing discussion. Marketing research is aimed at defining the role of brain reaction on marketing stimuli. The article undertakes an attempt to present the idea of neuromarketing research and the research methods. The research methods are sourced from neurology. The greatest attention was put on encephalography (EEG). There was also an analysis of potential for the method of its application and usage in advertising research. For that reason there was a laboratory experiment conducted with the presence of 20 people, aged 20-25. It proved the usability of the method in projecting efficient advertising campaigns. There were the limitations of the usage of technology enabling the process of brainwaves monitoring in neuromarketing research. The ethical issues related to neuromarketing were also highlighted.

Keywords: neuromarketing, neuromarketing research, electroencephalography (EEG), advertising. 


\section{Wstęp}

Początek XX w. to pojawienie się nowego nurtu w rozwoju marketingu, jakim jest neuromarketing i związane z nim badania. Neuromarketing jest rezultatem interdyscyplinarnego podejścia do marketingu. Adaptuje on bowiem wiedzę z zakresu medycyny, fizyki, biologii czy też chemii, aby przewidzieć i wyjaśnić reakcje (zachowania) konsumenta. Decydujący wpływ na rozwój neuromarketingu miały odkrycia neurobiologii (nowa wiedza na temat budowy mózgu człowieka i funkcji spełnianych przez poszczególne jego ośrodki) i psychologii. Lata 90. XX w. określano mianem dekady mózgu. Zdaniem A.R. Damasio [1999] w okresie tym nauka dowiedziała się o budowie mózgu i jego wpływie na funkcjonowanie umysłu więcej niż w całym poprzednim stuleciu. Wykorzystanie wiedzy neurobiologicznej pozwala na lepsze zrozumienie przebiegu takich procesów, jak emocje, uwaga, pamięć, podejmowanie decyzji [Ohme 2008]. Punktem zwrotnym okazała się Nagroda Nobla w dziedzinie ekonomii przyznana w 2002 r. psychologowi D. Kahnemanowi, współtwórcy ekonomii behawioralnej i powstałej dzięki niej neuroekonomii. Dorobek naukowy laureata podał w wątpliwość paradygmat ekonomii „homo oeconomicus” - człowieka racjonalnego, podejmującego świadome decyzje i wybory [Kahneman 2012]. Współczesne badania neurofizjologiczne wskazują, że nie uda się jasno oddzielić racjonalności od emocjonalności. Nie ma poznania bez emocji i emocji bez poznania. Nauka o ludzkim mózgu wskazuje na pierwotne filtrowanie wszystkich poczynań przez emocje [Shiller 2009]. Prowadzi to do rehabilitacji roli emocji w poznaniu ludzkim i połączeniu elementów racjonalnych i emocjonalnych w podejmowaniu decyzji [Sznajder 2008]. Wymusza to także zmianę metod prowadzenia badań oraz szukania sposobów działania zwiększających skuteczność i efektywność produktów rynkowych. Duża rola emocji w zachowaniach konsumentów nie musi oznaczać, że ich decyzje są podejmowane na podstawie bodźców innych niż dotychczas sądzono. W tym stanie rzeczy rośnie znaczenie neuromarketingu i badań neuromarketingowych, dzięki którym możemy poznać działanie ludzkiego mózgu w celu zdobycia informacji o potrzebach klientów, szczególnie tych nieuświadomionych, a tym samym lepiej zrozumieć proces decyzyjny konsumentów. Niestety, literatura dotycząca tej problematyki w języku polskim jest jeszcze uboga. Uzasadnione staje się zatem podejmowanie studiów poszerzających i pogłębiających naszą wiedzę z zakresu neuromarketingu. W nurt ten wpisuje się niniejsze opracowanie. Jego celem jest wyjaśnienie istoty badań neuromarketingowych oraz wskazanie na stosowane metody badawcze, ze szczególnym uwzględnieniem zastosowania elektroencefalografii (EEG).

\section{Istota badań neuromarketingowych}

H. Mruk [Mruk, Sznajder (red.) 2008, s. 5] ujmuje neuromarketing jako „ogół sposobów pomiaru aktywności mózgu człowieka związanych z bodźcami marketingowymi, takimi jak produkt, marka, opakowanie, cena, dystrybucja i promocja". Podobną definicję podaje M. Sznajder [2008, s. 121], traktując go ,jako gałąź nauki, 
w której bada się reakcje poznawcze, emocjonalne i sensomotoryczne na bodźce marketingowe". Z kolei P. Renovoice [Renovoice, Morin 2006] traktuje neuromarketing jako naukę o tym, jak ludzie używają mózgu do podejmowania decyzji, wykorzystującą nowe narzędzia, aby spojrzeć na to, co dzieje się w głowach konsumentów. Za ojca neuromarketingu uznaje się G. Zaltmana, który w 1998 r. na Uniwersytecie Harvarda przeprowadził badania, używając rezonansu magnetycznego do przeskanowania ludzkiego mózgu. Badania wykazały, że 95\% ludzkich zachowań i preferencji znajduje się w podświadomości [Zaltman 2003].

Podobnie jak w przypadku marketingu i badań marketingowych należy odróżnić neuromarketing, czyli marketing skierowany „do mózgu”, od badań neuromarketingowych, czyli badań zorientowanych na określenie „odpowiedzi mózgu” na bodźce marketingowe. Badania neuromarketingowe polegają na rejestracji i reakcji mózgu badanej osoby na prezentowane bodźce: przekazy reklamowe, produkty, ich smaki, zapachy, kolory itp. Ich celem - według P. Dobrodzieja - jest identyfikacja tych elementów prezentowanych treści, które powodują najsilniejsze reakcje emocjonalne (pozytywne-negatywne) oraz w największym stopniu koncentrują uwagę i zwiększają poziom pobudzenia u badanych osób [Krawiec 2015]. Obserwując aktywność określonych obszarów mózgu za pomocą metod znanych z medycyny, badania neuromarketingowe dążą głównie do zrozumienia reakcji emocjonalnych na bodźce. Czerpią one z doświadczeń długiej tradycji neurologii, która zbiera informacje o strukturach i funkcjach mózgu, a jej odnoga zwana neurokognitywistyką dąży do zrozumienia mechanizmów nerwowych, które odpowiadają za myślenie, rozumowanie, emocje, pamięć i podejmowanie decyzji. Pozwala to na ujawnienie ukrytych emocji, które świadomie lub nieświadomie nie znajdują odzwierciedlenia w odpowiedziach respondenta $\mathrm{w}$ wywiadzie bezpośrednim, będącym obecnie jedną z podstawowych metod badań rynku. Nawet w kontekście Big Data badania neuromarketingowe pozwalają na zdecydowanie dalej idącą analizę niż inne dostępne źródła danych. Badania neuromarketingowe czerpią - o czym już wspomniano - z długiej tradycji neurologii, w tym przede wszystkim wykorzystują technikę pomiaru fal mózgowych, czyli encefalografii (EEG). A.K. Pradeep, założyciel Neuro Focus, jeden $\mathrm{z}$ pionierów użycia encefalografii $\mathrm{w}$ badaniach neuromarketingowych, twierdzi, że badanie fal mózgowych odpowiada na zapotrzebowanie rynku na metodę dokładniejszego pomiaru preferencji respondentów, w obliczu istotnego błędu pomiaru innych powszechnie stosowanych metod w badaniach marketingowych. Jego zdaniem badania neuromarketingowe pozwalają na ocenę działań niektórych badań marketingowych ex ante, czyli przed ich podjęciem, poprzez ocenę reakcji mózgu respondenta na bodźce w postaci konceptów reklamowych. Odbiór bodźców wzrokowych następuje nie na poziomie oczu, ale na poziomie mózgu [Pradeep 2010].

Duński badacz M. Lindstrom [2009] wraz z naukowcami z Oxford University przeprowadził badania na grupie ponad 2000 respondentów na całym świecie, którym przedstawiono wiele materiałów reklamowych, takich jak logo, lokowanie produktu oraz reklamy drukowane. Na tej podstawie doszedł on do wniosku, że respondenci nie zawsze mówią to, co rzeczywiście myślą, a często nawet nie zdają sobie sprawy, czego 
rzeczywiście chcą. M. Lindstrom pokazuje jako przykład respondentów, którzy wyrażali niechęć do pewnych seriali telewizyjnych, kiedy jednocześnie badanie mózgu przeprowadzone za pomocą funkcjonalnego rezonansu magnetycznego (functional Magnetic Resonance Imaging - fMRI) wskazywało ich odmienne preferencje. Podobnie w przypadku ostrzeżeń o szkodliwości palenia na paczkach papierosów. Mimo że palacze deklarują brak ich skuteczności, badania mózgu wskazują jednoznacznie aktywność w obszarze mózgu zwanym grzbietowo-boczną korą przedczołową (Dorsolateral Prefrontal Cortex - DPC), która jest odpowiedzialna za kontrolę zachowania.

M. Lindstrom wskazał również, że inne zmysły, takie jak słuch i węch, mają znacznie większy wpływ na preferencje konsumentów niż wzrok. Podkreśla on znaczenie marki oraz zaangażowania emocjonalnego, stawiając tezę, że ludzkie decyzje o zakupie opierają się głównie na czynnikach emocjonalnych, a nie racjonalnych. W tym kontekście rozwój metod badania emocji za pośrednictwem badania aktywności mózgu staje się kluczowy dla budowania skutecznego przekazu marketingowego. Jednocześnie jednak warto zwrócić uwagę, że mózg jest niezwykle skomplikowany i nie wystarczy zaobserwować aktywności w jednej części mózgu, aby definitywnie stwierdzić, że osoba badana odczuwa właśnie określone emocje. Badania nie potwierdziły, że określone emocje mogą być w sposób konsekwentny zawsze przypisane do określonej części mózgu. Wręcz przeciwnie, wiele wskazuje na to, że są one zlokalizowane w wielu powiązanych ze sobą obszarach, a zatem również interpretacja wyników badania jest niezwykle trudna.

Największym wyzwaniem dla badań neuromarketingowych będzie zatem stworzenie wiarygodnego sposobu interpretowania danych. Medyczne metody pomiaru aktywności mózgu pozwalają na rejestrację ogromnej liczby danych, ale ich analiza może sprawić trudność nawet biegłemu lekarzowi neurologii. Tym trudniej jest analizować te dane w kontekście motywów postępowania czy też preferencji konsumentów w stosunku do produktów, a także przekazu reklamowego.

\section{Metody badań neuromarketingowych}

Neuromarketing wykorzystuje aparaturę i metody badań stosowane w medycynie, fizyce i chemii, natomiast układ badań realizuje założenia marketingowe. Dominują metody zaczerpnięte z neurologii, mierzące poziom aktywności mózgu, fal mózgowych oraz procesów metabolicznych mózgu. Podstawowe metody neuromarketingowe uwzględniają:

- EEG (Electroencephalography), czyli elektroencefalografię,

- TMS (Transcranial Magnetic Stimulation), czyli przezczaszkową stymulację magnetyczną,

- fMRI (functional Magnetic Resonanse Imaging), czyli funkcjonalny rezonans magnetyczny,

- oraz PET (Positron Emission Tomography), czyli pozytonową tomografię emisyjną. 
Ponadto w szerszym ujęciu, wykraczającym poza bezpośrednią odpowiedź mózgu, coraz większe znaczenie w poznaniu preferencji konsumentów odgrywają badania biofeedback (biologiczne sprzężenie zwrotne) i eye-tracking (badanie ruchu gałek ocznych).

Neuromarketing wykorzystuje przede wszystkim technikę pomiaru fal mózgowych, czyli encefalografii (EEG), użytej po raz pierwszy przez Hansa Bergera w 1924 roku w oparciu o wcześniejsze prace pomiarowe aktywności mózgu Richarda Catona [Duch 2008]. Analiza fal mózgowych pokazuje świat trójwymiarowo. Wcześniej widzieliśmy wszystko w dwóch wymiarach, płasko [Ohme 2008]. P.L. Nunez i R. Srinivasan [2006] stwierdzają, iż EEG jest naszym „oknem na umysł". Mimo większej precyzji aparatów fMRI, ze względu na koszty idące w miliony złotych w przypadku rezonansu magnetycznego, większość komercyjnych ofert badań rynku z użyciem technik neuromarketingowych opiera się na aparatach EEG. Aparaty EEG nie należą do najtańszych, ale ich koszt jest zdecydowanie niższy od kosztu fMRI i porównywalny ze stosunkowo często stosowanym pomiarem ruchu gałek ocznych. Jednocześnie, jak wykazali Grummett i in. [2015], tanie, komercyjne, bezprzewodowe aparaty, takie jak Emotiv EPOC, B-Alert oraz g.Sahara, są porównywalnie skuteczne $\mathrm{w}$ wielu obszarach jak typowo laboratoryjny sprzęt EEG HIamp. Dzięki użyciu bezprzewodowych, tanich, suchych aparatów możliwe jest przeprowadzanie badań na większych próbach poza laboratorium, na przykład w supermarkecie, samochodzie, w domu. Badanie EEG polega na wielokanałowym zapisie z 19 lub więcej elektrod. Zapis czynności mózgu jest podobny do zapisu pracy serca EKG. Czujniki zapisujące sygnał mózgu są umiejscowione nie na klatce piersiowej, ale na głowie badanego. Amplitudy zapisanych fal mózgowych odpowiadają konkretnym stanom psychicznym, takim jak słabość (fale beta), relaksacja (fale alfa), spokój/otwartość (fale theta) oraz sen (fale delta). Ponadto aktywność fal mózgowych w określonym obszarze mózgu wskazuje na reakcje respondenta na określone bodźce. Poprzez zlokalizowanie, która część mózgu jest aktywna podczas stymulowania go statycznym obrazem, materiałem dźwiękowym lub materiałem wizualno-dźwiękowym można określić pozytywne lub negatywne przełożenie odbioru przez konsumenta [Małecki 2008]. Już w 1990 roku, korzystając z aparatu EEG, R. Davidson [Davidson, Ekman 1990] doszedł do wniosku, że stosunkowo prosta analiza fal mózgu, wskazująca na aktywność prawej lub lewej półkuli, pozwala na zidentyfikowanie, czy określony bodziec wywołuje u respondenta pozytywne emocje związane z otwartością czy negatywne emocje związane z wycofaniem oraz odrazą. R. Davidson przypisał aktywność lewej półkuli mózgu pozytywnym emocjom szczęścia, a prawej półkuli - negatywnym emocjom odrazy i wycofania.

EGG jest jednak zdolne zapisywać jedynie aktywność wierzchnich warstw kory mózgowej. Dlatego wciąż zainteresowaniem niektórych badaczy cieszą się znacznie droższe i mniej powszechne urządzenia służące do badania aktywności mózgu. Jednym $z$ nich jest funkcjonalny magnetyczny rezonans jądrowy (fMRI). Łączy on pole magnetyczne z falami radiowymi, wytwarzając sygnał pozwalający zobaczyć szczegóły struktur mózgowych oraz śledzić aktywność metaboliczną w mózgu. Jak wyjaś- 
nia L. Żurawicki [2010]., badana osoba leży na łóżku, z głową otoczoną dużym magnesem, który powoduje wyrównanie się cząsteczek subatomowych (protonów) do linii pola magnetycznego. Ponieważ krew zawiera żelazo, atomy żelaza, które nie są połączone $\mathrm{z}$ tlenem, wytwarzają małe zakłócenia w pobliskim polu magnetycznym i podczas gdy określona cześć mózgu jest aktywna, odpowiadające jej żyły rozszerzają się, krew przepływa w większej ilości, redukując część beztlenowej hemoglobiny i produkując zmianę w polu magnetycznym w aktywnym miejscu. Oprogramowanie pozwala zaobserwować dane zmiany, wyświetlając zakolorowane miejsca na szarym zdjęciu mózgu. fMRI pozwala na pomiar aktywności mózgu oraz poszukiwanie schematów, w czasie gdy badany obiekt wykonuje konkretne czynności bądź doświadcza bodźców marketingowych. Analizy danych mogą zostać przeprowadzone z użyciem specjalnego oprogramowania, takiego jak BrainVoyager QX lub Statistical Parametric Mapping (SPM5) [Falk i in. 2009; Plassmann i in. 2007]. Niestety, według N. Lee $i$ in. [2009] fMRI reprezentuje jedynie odpowiednią metodologię odkrywania obszarów aktywności mózgu w reakcji na bardzo proste konstrukcje eksperymentalne, z niewielkim potencjałem, z powodu problemu wymiaru czasowego.

Kolejną metodą wykorzystywaną w badaniach neuromarketingowych jest pozytonowa tomografia emisyjna (PET). Podobnie jak fMRI jest to kosztowna metoda prowadząca do uzyskania obrazów psychograficznych o rozkładzie przestrzennym. Działanie polega na monitorowaniu promieniowania emitowanych pozytonów z substancji radioaktywnej podanej obiektowi. Zbiór czujników otacza głowę obiektu, śledzi promieniowanie, bez precyzyjnego określenia lokalizacji sygnału. Techniczne problemy to między innymi pozyskanie oraz krótki okres życia radioaktywnej substancji. Natomiast magnetoencefalografia (MEG) używa potencjału magnetycznego, aby zapisywać aktywność mózgu na poziomie czaszki. Wyposażony w bardzo czułe czujniki kask jest umieszczony na głowie badanej osoby. Pole magnetyczne w odróżnieniu od elektrycznego nie jest zakłócane przez żaden typ tkanki (krew, substancje biała i szara, kości) i może wskazywać głębokość miejsca w mózgu z dużą rozdzielczością przestrzenną i czasową. L. Żurawicki [2010] twierdzi, że eksperymenty $\mathrm{z}$ użyciem MEG wymagają pokoju odizolowanego od ziemskiego pola magnetycznego, co sprawia, że metoda ta ma bardzo wąskie zastosowanie.

Większą nadzieję na powszechne zastosowanie rodzi przezczaszkowa stymulacja magnetyczna (TMS), która używa indukcji magnetycznej do modulowania aktywności mózgu w określonych obszarach zlokalizowanych ok. $2 \mathrm{~cm}$ wewnątrz, nie sięgając do kory. Nowa technologia TMS pozwala na badanie niższych obszarów mózgu i jest tańsza od skanerów PET czy fMRI. TMS wyładowuje pole magnetyczne, które przechodząc przez mózg, pozwala na zmiany w tkance mózgowej w określonych miejscach i może aktywować neurony (z użyciem wysokich częstotliwości) bądź na pewien czas je dezaktywować (niska częstotliwość).

Opisane powyżej narzędzia neuroobrazowania są obecnie powszechnie używane w zestawieniu z urządzeniami służącymi do śledzenia ruchu gałek ocznych. W szczególności bezprzewodowe EEG w połączeniu z bezprzewodowymi okularami (eye 
tracking) może być stosowane do oceny skuteczność ekspozycji w punktach sprzedaży (POS). Jak w lutym 2015 r. podczas konferencji Quirks w Nowym Jorku wskazywał Scott Young, CEO Perception Research Services, zastosowanie takiej metodologii może pomóc w zwiększeniu skuteczności komunikacji w punktach sprzedaży.

Inną metodą wchodzącą w szerszy krąg neuromarketingu jest obserwowanie reakcji psychologicznych na bodźce, które może dostarczyć informacji na temat efektów emocjonalnych występujących u osoby badanej, poprzez monitorowanie tętna, ciśnienia, przewodnictwa skóry (pod wpływem potu, mierzenie poziomu pobudzenia), hormonu stresu w ślinie, skurczy mięśni ciała i wnioskowanie o emocjonalnym stanie w każdym momencie. Ponadto dość powszechnie stosowany jest pomiar czasu na bodźce. Podczas takich badań oblicza się czas reakcji pomiędzy pojawieniem się bodźca a reakcją na niego. Czas reakcji informuje badaczy o stopniu skomplikowania bodźca w odniesieniu do respondenta i stosunku osoby badanej do tegoż bodźca. Według L. Żurawickiego [2010] ta tania metoda może zostać wykorzystana do określenia podejścia osoby badanej do konkretnych bodźców.

\section{Zastosowanie EEG w badaniu reklamy w kontekście przeprowadzonego testu laboratoryjnego}

Neuromarketing już dzisiaj jest wykorzystywany w wielu sferach biznesu, w tym m.in. w farmacji, przemyśle motoryzacyjnym, muzycznym, a szczególnie w branży mediów. Badanie neuromarketingowe pomagają lepiej zrozumieć zachowania konsumenta, a co za tym idzie - umożliwiają tworzenie jeszcze skuteczniejszych kampanii reklamowych.

\subsection{Opis badania}

Na potrzeby niniejszego opracowania przeprowadzono wstępne badanie mające na celu ocenę możliwości użycia jednej z podstawowych metod neuromarketingowych, jaką jest EEG, w testowaniu reklam. Intencją było również uzyskanie - tym sposobem - prostego i łatwego do interpretacji modelu, który mógłby służyć za podstawę w kolejnych badaniach na większych próbach. Punktem odniesienia do wyników badania neuromarketingowego było realizowane w tym samym czasie, na tej samej próbie badanie tradycyjną metodą wywiadu kwestionariuszowego. Pozwoliło to na porównanie rezultatów obu badań, oceniających zaprezentowane przekazy reklamowe, głównie w kontekście ich skuteczności. Należy wyraźnie podkreślić, iż w przeprowadzonym eksperymencie nie chodziło o wykazanie wyższości jednej czy drugiej metody, ale o ustalenie, czy EEG może stanowić użyteczne narzędzie badawcze przy tworzeniu kampanii reklamowych, w tym przede wszystkim skutecznych przekazów reklamowych.

Do udziału w eksperymencie zaprosiliśmy 20 osób w wieku od 20 do 27 lat. Wszystkie osoby były w pełni zdrowe, nie zgłaszały żadnych problemów natury 
neurologicznej oraz były praworęczne. Powodem wyboru takich osób była chęć uniknięcia ewentualnych zaburzeń pomiaru, w szczególności tych związanych z odmiennym funkcjonowaniem mózgu osób prawo- i leworęcznych, co mogłoby prowadzić do błędnej interpretacji wyników.

Eksperyment został przeprowadzony w studiu badawczym i-view Warsaw. Wszyscy uczestnicy otrzymali poczęstunek oraz ciepłe napoje w celu osiągnięcia relaksującej atmosfery. Każdy uczestnik otrzymał również pełną informację o celach oraz przebiegu badania i wyraził zgodę na udział w badaniu oraz analizę danych w zaprezentowanej formie.

Do pomiaru aktywności mózgu użyto aparatu Nexus firmy MindMedia. Został on umieszczony na głowie każdego z uczestników w trakcie, kiedy uczestnicy oglądali 5 reklam telewizyjnych, o długości ok. 30 sekund, przypadkowo dobranych marek produktów spożywczych: Oreo, Belvita, Prince Polo, Tymbark i Hellmann's. Uczestnicy oglądali reklamy indywidualnie na ekranie telewizora umieszczonego bezpośrednio przed nimi, siedząc na wygodnym fotelu. Kolejność wyświetlania reklam była rotowana. Hałas oraz inne bodźce zewnętrzne zostały ograniczone do minimum w celu wyeliminowania wszelkich okoliczności mogących zakłócić uwagę uczestników.

W badaniu postrzeganej skuteczności reklamy metodą wywiadu bezpośredniego wykorzystano zmodyfikowaną metodę zasugerowaną przez S. Rosengren [Rosengren, Dahlén, Okazaki 2013], uzupełnioną o pytania dotyczące osobistych preferencji oraz motywacji do zakupu. Po obejrzeniu każdej z 5 reklam uczestnicy zostali poproszeni o ustosunkowanie się do poniższych stwierdzeń poprzez zastosowanie 7-stopniowej skali Likerta, gdzie 1 = zdecydowanie nie zgadzam się, a 7 = zdecydowanie zgadzam się. Stwierdzenia brzmiały następująco:

Uważam, że zaprezentowana reklama zwiększy sprzedaż [Produktu X].

Uważam, że zaprezentowana reklama będzie lubiana przez konsumentów.

Uważam, że reklama zwiększa świadomość [Produktu X].

Reklama [Produktu X] bardzo mi się podoba.

Reklama [Produktu X] jest wiarygodna.

Reklama [Produktu X] przekonuje mnie do zakupu.

W wyniku badania dla każdego uczestnika uzyskano odpowiedzi na pytania kwestionariuszowe oraz zapis reakcji mózgu na każdą z zaprezentowanych reklam.

Celem wywiadu bezpośredniego było w pierwszym kroku wyselekcjonowanie dwóch reklam o skrajnych ocenach dotyczących ich skuteczności. W drugim kroku natomiast skoncentrowano się na porównaniu wyników badania osiągniętych metodą wywiadu bezpośredniego z wynikami badania EEG w odniesieniu do tych samych reklam.

\subsection{Wyniki badania}

Zagregowane wyniki odpowiedzi na pytania kwestionariusza wywiadu, które stanowiły punkt odniesienia dla dalszej analizy, pozwoliły na wyselekcjonowanie dwóch reklam, które uzyskały najwyższą i najniższą ocenę: Tymbark z wynikiem 5.2 oraz Hellmann's z wynikiem 3.7. 
W następnym kroku, korzystając z oprogramowania EEG Mindmedia, porównano obszary mózgu aktywowane podczas oglądania obu reklam. Badanie wykazało, że w przypadku reklamy Tymbark, czyli reklamy, która w wywiadzie bezpośrednim uzyskała zdecydowanie wyższą ocenę respondentów, mogliśmy zaobserwować większą aktywność fal theta w przyśrodkowej części przedniej mózgu. Aktywność fal theta może oznaczać aktywowanie ośrodków odpowiedzialnych za zapamiętywanie i przyjmowanie informacji, co może świadczyć o większej skuteczności tej reklamy.

Jednocześnie obserwacja fal theta w kontekście prawej i lewej półkuli dowiodła, że obie reklamy wywołały aktywacje lewej półkuli mózgu, z tym że aktywność fal theta w przypadku reklamy Tymbark była większa. Zgodnie z modelem R. Davidson [Davidson, Ekman 1990] aktywność lewej półkuli mózgu wskazywać może na pozytywne emocje, w przeciwieństwie do aktywności prawej półkuli mózgu, która mogłaby oznaczać odrazę i odrzucenie. W tym kontekście zatem obie reklamy wywołały emocje pozytywne, a różnice zaobserwować można było jedynie w intensywności tych emocji.

Podsumowując, wyniki wywiadu bezpośredniego dla reklamy Tymbark i reklamy Hellmann's pokrywały się z wynikami analizy zapisu EEG. O ile na podstawie badań trudno byłoby określić skale różnicy w ocenach obu reklam, o tyle w sposób bezsporny można było stwierdzić, która reklama jest bardziej skuteczna oraz która budzi pozytywne emocje.

\subsection{Konkluzje}

Badania z wykorzystaniem encefalografii wydają się stanowić godne zaufania źródło danych na temat preferencji respondentów w stosunku do reklam. Dalsze badania są potrzebne $\mathrm{w}$ celu potwierdzenia precyzji danych pozyskanych w ten sposób oraz zasadności zastosowania techniki droższej od tradycyjnego badania metodą wywiadu. Ponadto kluczowy obszar zastosowania EEG to ujawnianie emocji ukrytych, niewyrażanych w wywiadzie bezpośrednim.

W tym kontekście EEG może być bezcennym narzędziem pozwalającym zidentyfikować przekaz niepożądany, który ze względu na przykład na poprawność polityczną oceniany jest pozytywnie w wywiadzie bezpośrednim, ale faktycznie wywołuje negatywne emocje. Podobnie, w odwrotnym przypadku, gdzie pozytywne emocje wywołuje przekaz społecznie uznawany za niepożądany.

Można sobie wyobrazić wiele takich sytuacji odnoszących się do przekazu mającego inny oddźwięk w różnych kulturach, religiach, a na gruncie Polski - w przypadku różnic wynikających z płci lub przekonań respondenta. Metoda EEG może być bardziej skuteczna w sytuacji oceny zachowania impulsywnego. Ponadto metoda ta może być również stosowana do oceny bardziej kompleksowych informacji, $\mathrm{np}$. konceptów produktów w połączeniu z metodą conjoint.

Pozwoliłoby to na znaczące ograniczenie czasu potrzebnego do oceny wielu scenariuszy. Teoretycznie nawet krótka ekspozycja koncepcji produktu powinna być 
wystarczająca, żeby ocenić atrakcyjność konceptu za pomocą metody EEG. Prezentacja i ocena kilkunastu scenariuszy z kilkoma atrybutami zajęłaby zaledwie 2-3 minuty, w przeciwieństwie do obecnych kilkunastu. Niezbędne są zatem dalsze badania zastosowania metody EEG na tym polu.

\section{Ograniczenia badań neuromarketingowych}

Wdrażanie technik neuromarketingowych stanowi obiecującą przyszłość dla badań marketingowych; niemniej jednak ta nowa praktyka spotyka się z licznymi ograniczeniami, włączając w to koszty, złożoność oraz czasami rozmiary urządzeń, takich jak skanery fMRI [Bogue 2010] Zgodnie z Kenningiem i in. [2007], typowy skaner fMRI może kosztować pomiędzy 1 a 2 miliony euro, zależnie od rozdzielczości oraz innych zmiennych, takich jak koszty oprogramowania, utrzymania sprzętu, stawek profesjonalistów, jak i kosztownego procesu chłodzenia cewek magnetycznych w urządzeniu. Może to podnieść koszty badań do rozmiarów znacznie większych niż przy konwencjonalnych metodach marketingowego badania rynku. Dlatego właśnie badanie metodą EEG, którego koszt gwałtownie spada w ostatnim czasie, a sprzęt służący do prowadzenia badania tanieje z roku na rok, wydaje się zdecydowanie najbardziej realną opcją dla badaczy marketingowych.

Badania neuromarketingowe z zastosowaniem innych urządzeń niż EEG stanowią istotny problem logistyczny oraz mogą mieć wpływ na respondenta i jego zdolności postrzegania oraz przetwarzania informacji. Otoczenie medyczne, gigantycznych rozmiarów urządzenie wydające głośny dźwięk oraz ograniczenie przestrzeni mogą również utrudniać postrzegania, jeśli porównamy to do sposobu przetwarzania bodźców marketingowych, które są odbierane w rzeczywistym świecie. Dla przykładu, badanie przy użyciu fMRI, sprawdzające postrzeganie wiarygodności ofert na serwisie eBay, jest trudne do przeprowadzenia. Przyjmuje się, że przy takim badaniu kupujący online powinni komfortowo usadowić się naprzeciw swoich komputerów i w spokojnych warunkach studiować oferty na eBayu. Sytuacja ta jest niemożliwa do wprowadzenia w realnych, doświadczalnych warunkach ze względu na rozmiar urządzenia fMRI, jak również z powodu istnienia specjalnego pomieszczenia do kontroli bezpieczeństwa zarówno podmiotów, jak i badaczy [Riedl i in. 2010]. Jednak już zastosowanie znacznie tańszych mobilnych urządzeń komercyjnych EEG pozwala na stworzenie wymaganych warunków badania.

Neuromarketing może budzić obawy etyczne. Warto zastanowić się, w jakim stopniu wiedza z zakresu nauk medycznych powinna być wykorzystywana do badania oraz manipulowania zachowaniem konsumentów. Wraz z rozwojem neuromarketingu i związanych z nim badań należy równolegle stworzyć kodeks zasad etycznych, którymi powinni kierować się badacze. W tym kontekście niezwykle ważna będzie rola międzynarodowych organizacji, takich jak ESOMAR [Gregor, Kalińska-Kula 2014]. 


\section{Zakończenie}

Neuromarketing rozumiany jako nowy obszar marketingu i badań marketingowych, opierających się na zastosowaniu technologii umożliwiającej monitorowanie pracy mózgu, odgrywa coraz większą rolę w gromadzeniu wiedzy o konsumentach. Dając możliwość głębszego poznania potrzeb, preferencji oraz - co szczególnie ważne motywów zachowań konsumentów, ułatwia firmom zdobycie przewagi konkurencyjnej na rynku. Trudno wyobrazić sobie obecnie międzynarodowy koncern pracujący w jakiejkolwiek dziedzinie gospodarki, który byłby obojętny w stosunku do neuromarketingu. Głównym punktem zainteresowania menedżerów jest znaleźć takie bodźce, które trafią do podświadomości ludzkiej i zostaną zapamiętane, ale również przełożą się na oczekiwane przez nich zachowanie konsumenta. Wyniki badań neuromarketingowych ostatecznie służą przygotowaniu skutecznych strategii marketingowych, w tym przede wszystkim strategii komunikacji marketingowej.

Neuromarketing wykorzystuje głównie metody badań zaczerpnięte z neurologii, w tym technikę pomiaru fal mózgowych, czyli elektroencefalografię (EEG). Realizacja badań neuromarketingowych nie jest sprawą prostą. Wymaga ona wyspecjalizowanego zespołu osób z wykształceniem z zakresu neurobiologii i neuropsychologii. Wiele wskazuje na to, że wbrew opinii prekursorów neuromarketingu proces decyzyjny konsumentów jest zdecydowanie bardziej skomplikowany; nie ma jednego tzw. „przycisku kupującego”. Każda decyzja wzmaga różne obszary w mózgu, które są sterowane w różnych kierunkach, zależnie od wielu czynników. Niemniej neuroobrazowanie jest w stanie rozszyfrować ludzki mózg, podkreślając aspekty emocjonalne lub kognitywne. Mając na względzie ważność emocji przy motywowaniu zachowania konsumenta, ranga badań neuromarketingowych będzie rosła.

Obawy dotyczące prywatności oraz etyki w badaniach neuromarketingowych są uzasadnione. Środowisko badaczy rynku powinno samo przejąć inicjatywę w regulacji tej kwestii, wypracowując etyczne rozwiązania służące wszystkim zainteresowanym.

\section{Literatura}

Bogue R., 2010, Brain-computer interfaces: control by thought, Industrial Robot: An International Journal, vol. 37, s. 126-132.

Damasio A.R., 1999, Błąd Kartezjusza. Emocje, rozum i ludzki mózg, Rebis, Poznań.

Davidson R., Ekman P., 1990, Approach-withdrawal and cerebral asymmetry: Emotional expression and brain physiology, Journal of Personality and Social Psychology, vol. 58(2), s. 330-341.

Duch W., 2008, Perspektywy neuromarketingu, [w:] Mruk H., Sznajder M. (red.), Neuromarketing. Interdyscyplinarne spojrzenie na klienta, Wydawnictwo Uniwersytetu Przyrodniczego w Poznaniu, Poznan.

Falk E.B., Rameson L., Berkman E.T., Liao B., Kang Y., Inagaki T.K., Lieberman M.D., 2009, The Neural Correlates of Persuasion. A Common Network across Cultures and Media, Journal of Cognitive Neuroscience, vol. 22(11), s. 230-237. 
Fisher C.E., Chin L., Klitzman R., 2010, Defining neuromarketing: Practices and professional challenges, Harvard Review of Psychiatry, 18(4), 230-237.

Gregor B., Kalińska-Kula M., 2014, Badania marketingowe na użytek decyzji menedżerskich, Wydawnictwo Uniwersytetu Łódzkiego, Łódź.

Grummett T.S., Leibbrandt R.E., Lewis T.W., DeLosAgeles D., Powers D.M.W., Willoughby J.O., Pope K.J., Fitzgibbon S.P., 2015, Measurement of neural signals from inexpensive, wireless and dry EEG systems: http://iopscience.iop.org/article/10.1088/09673334/36/7/1469;jsessionid=8927 0265D55D179C4A00488890AE7C5E.c1 (20.10.2015).

Kahneman D., 2012, Pułapki myślenia. O myśleniu szybkim i wolnym, Wydawnictwo Media Rodzina, Poznań.

Kenning P., Plassmann H., Ahlert D., 2007, Applications of functional magnetic resonance imaging for market research, Qualitative Market Research. An International Journal, vol. 10(2), s. 135-152.

Krawiec W., 2015, Badania neuromarketingowe - sposób na odkrycie nieuświadomionych zachowań i relacji klienta, [w:] Wiażewicz J., Zielińska A., Determinanty i efekty wspótczesnej aktywności marketingowej, Oficyna Wydawnicza Politechniki Rzeszowskiej, Rzeszów.

Lee N., Senior C., Butler M., Fuchs R., 2009, The Feasibility of Neuroimaging Methods in Marketing Research. Nature Proceeding, http://precedings.nature.com/documents/2836/version/1 (6.02.2016).

Lindstrom M., 2009, Zakupologia. Prawda i kłamstwa o tym dlaczego kupujemy, Wydawnictwo Znak, Kraków.

Małecki T., 2008, Neuroplanowanie mediów, [w:] Mruk H., Sznajder M. (red.), Neuromarketing. Interdyscyplinarne spojrzenie na klienta, Wydawnictwo Uniwersytetu Przyrodniczego w Poznaniu, Poznań.

Mruk H., Sznajder M. (red)., 2008, Neuromarketing. Interdyscyplinarne spojrzenie na klienta, Wydawnictwo Uniwersytetu Przyrodniczego w Poznaniu, Poznań.

Nunez P.L., Srinivasan R., 2006, Electric Fields of The Brain. The Neurophysics of EEG, Oxford University Press, Oxford.

Ohme R.K., 2008, Koniec romantycznej reklamy, [w:] Mruk H., Sznajder M. (red.), Neuromarketing. Interdyscyplinarne spojrzenie na klienta, Wydawnictwo Uniwersytetu Przyrodniczego w Poznaniu, Poznań.

Plassmann H., O'Doherty J., Rangel A., 2007, Orbitofrontal cortex encodes willingness to pay in everyday economic transactions, Journal of Neuroscience, vol. 27(37), s. 9984-9988.

Pradeep A.K., 2010, The Buying Brain: Secrets for Selling to the Subconscious Mind, John Wiley \& Sons.

Renovoice P., Morin C., 2006, Neuromarketing - Selling to the Old Brain for Instant Success, Sales Brain Publishing, San Francisco.

Riedl R., Hubert M., Kenning P., 2010, Are there neural gender differences in online trust? An fMRI study on the perceived trustworthiness of eBay offers, Mis Quarterly, Issue 34, Society for Information Management and The Management Information Systems Research Center Minneapolis, s. 397-428.

Rosengren S., Dahlén M., Okazaki S., 2013, Advances in Advertising Research, Springer Gabler.

Shiller R.J., 2009, Irrational Exuberance, Princeton University Press, Princeton - Oxford.

Sznajder M., 2008, Podsumowanie. Problematyka, pojęcia, definicje stosowane w neuromarketingu, [w:] Mruk H., Sznajder M. (red.), Neuromarketing. Interdyscyplinarne spojrzenie na klienta, Wydawnictwo Uniwersytetu Przyrodniczego w Poznaniu, Poznań.

Zaltman G., 2003, Jak myśla klienci. Podróż w głąb umystu rynku, Forum, Poznań.

Żurawicki L., 2010, Neuromarketing: Exploring the brain of the consummer, Springer, Berlin - Heidellberg. 